\title{
Un ejército de muchos nombres. La difícil formación de las fuerzas militares rioplatenses en la guerra entre las Provincias Unidas y el Imperio del Brasil
}

\author{
An army of many names. \\ The difficult formation of the Rio de la Plata military forces \\ in the war between the United Provinces and the Empire of \\ Brazil
}

Gabriel Di Meglio

Instituto Ravignani, CONICET-UBA

Recibido: 06/08/2018

UNSAM, Argentina

Aprobado: 24/10/2018

Resumen. La formación del ejército de las Provincias Unidas del Río de la Plata para enfrentar al Imperio brasileño después del levantamiento oriental de 1825 fue una tarea muy complicada para el frágil Estado central que se intentaba crear en ese momento. El artículo explora, a través de distintos tipos de fuentes, el esfuerzo económico, la dificultad para conseguir soldados, las reacciones populares provocadas por los abusos del reclutamiento forzoso (deserciones, sublevaciones y la circulación de "las ideas de Don José Artigas"), las tensas relaciones entre las provincias y el gobierno "nacional", los inconvenientes de este con los orientales y los entrerrianos, el uso del republicanismo como clave ideológica. El problemático armado de este ejército "de observación”, luego "de operaciones”, que confluyó con el "ejército oriental" en el "ejército nacional", rebautizado "ejército republicano", permite analizar las enormes dificultades de construcción estatal en el período posrevolucionario, los límites de la llamada "militarización” y las razones del fracaso del proyecto unitario.

Palabras clave: Ejército - Guerra - Unitarios - Republicanismo - Independencia uruguaya 
Abstract. The formation of the army of the United Provinces of the Rio de la Plata to confront the Brazilian Empire after the Oriental uprising of 1825 was a very complicated task for the fragile central State that was trying to be created. The article explores, through different types of sources, the economic effort, the difficulty to obtain soldiers, the popular reactions provoked by the abuses of forced recruitment (desertions, mutinies and the circulation of "the ideas of Don José Artigas"), the tense relations between the provinces and the "national" government, the problems of the latter with the Orientales and the Entrerrianos, the use of republicanism as an ideological key. The problematic construction of this "Army of Observation", then "of Operations", that came together with the "Oriental Army" in the "National Army", renamed "Republican Army", allows to analyze the enormous difficulties of State-building in the post-revolutionary period, the limits of the so-called "militarization" and the reasons for the failure of the Unitarian project.

Key Words: Army - War - Unitarians - Republicanism - Uruguayan Independence

\section{Introducción}

El enfrentamiento de las Provincias Unidas del Río de la Plata con el imperio del Brasil entre 1825 y 1828 fue varias cosas al mismo tiempo: una prolongación de la lucha por la independencia de la región platense, la primera guerra librada entre países iberoamericanos independientes, la herencia del conflicto secular entre españoles y portugueses por el control de la cuenca del Plata, y una disputa por stocks de ganado bovino.

Distintas cuestiones militares, diplomáticas y políticas de la "Guerra con el Brasil" o "Guerra da Cisplatina" han sido abundantemente tratadas por las historiografías argentina, brasileña y uruguaya a lo largo del tiempo, en textos específicos y en obras generales sobre la época. El objetivo de este artículo es explorar una cuestión poco analizada en ellas: cómo se formó el ejército que combatió del lado rioplatense. Poner el eje en él, en su heterogénea composición y en su movilidad, permite eludir el conocido riesgo historiográfico de proyectar hacia 
atrás las fronteras nacionales que terminaron de consolidarse décadas después del conflicto. A la vez, la construcción de esta fuerza militar es un excelente objeto para entrecruzar las perspectivas estructurales con las culturales, combinar la movilización de hombres, mujeres y recursos con sus razones para pelear y para tratar de no hacerlo. El estudio es "al ras del suelo", utilizando los documentos creados en ese mismo momento, atendiendo a las intervenciones de múltiples actores y no solo las de los líderes, y teniendo en cuenta las conflictividades partidarias y regionales. ${ }^{1}$ Se evita explícitamente intervenir en los debates binarios clásicos, porque pueden trabar la comprensión de lo ocurrido, sea la antigua y extensa discusión de la historiografía uruguaya acerca de si el movimiento de 1825 fue unionista o independentista, o la vasta producción argentina sobre las responsabilidades de unitarios y federales en el devenir de la guerra, cuestión entremezclada habitualmente con la dicotomía Buenos Aires-Interior. ${ }^{2}$

En un momento de primacía de las provincias como formas viables de organización administrativa, darle vida a ese ejército se asoció al esfuerzo por crear un Estado de alcance supraprovincial. Su organización implicó una serie de conflictos y complicaciones materiales, sociales, políticas y simbólicas que vale la pena dilucidar para entender las enormes dificultades de construcción estatal tras la ruptura del vínculo colonial.

\footnotetext{
${ }^{1}$ Las fuentes utilizadas son cartas, oficios y otros manuscritos intercambiados por militares y autoridades -a veces a través de las plumas de los secretarios- en 1825 y 1826, provenientes de diferentes archivos. Muchas de las conservadas en el Archivo General de la Nación en Uruguay (en adelante AGN/U) han sido publicadas por el Boletín Histórico publicado por el Estado Mayor del Ejército, y han sido empleadas por la historiografía; otras no. Las del Archivo General de la Nación de Argentina (AGN/A) han sido menos usadas. Aquí se complementan con debates parlamentarios, periódicos, juicios, diarios de marcha de los oficiales, y memorias redactadas por algunos de ellos, que por lejanía temporal con los hechos deben usarse con mayor cuidado.

2 La bibliografía en todos estos temas es tan amplia que es imposible listarla solo por marcar los títulos. En lo que sigue iré citando distintos trabajos de los que tomo información, lo cual no le hace justicia a la nutrida biblioteca sobre el conflicto; motivos de espacio fundamentan esta decisión. En los últimos años se han publicado algunas investigaciones sobre diversos aspectos de la guerra que realizan aproximaciones muy ricas. Véanse sobre todo los trabajos reunidos en FREGA, Ana (coord.), Historia regional e independencia del Uruguay. Proceso histórico y revisión crítica de sus relatos, Montevideo, Ediciones de la Banda Oriental, 2009; y también PIMENTA, João Paulo, Estado y nación hacia el final de los Imperios ibéricos. Río de la Plata y Brasil, 1808-1828, Buenos Aires, Sudamericana, 2011.
} 
A lo largo de un año y medio, la fuerza pasó de ser llamada "ejército de observación" a "ejército de operaciones", confluir luego con el "ejército oriental" (denominado por algunos "ejército provincial") en el "ejército nacional”, y ser finalmente rebautizada “ejército republicano". Estos nombres cambiantes no son el eje de la investigación, pero sí sirven como un indicador muy gráfico de la complejidad y fragilidad del proyecto del cual ese ejército era parte fundamental.

\section{"Nacional o de provincia"}

Mientras en Salta, que incluía Jujuy, la guerra de independencia continuó siendo una realidad en la primera mitad de la década de 1820 -hasta principios de 1825 el Alto Perú estuvo en manos de los leales al rey español, que realizaban incursiones anuales sobre tierras jujeñas-, el resto de las provincias rioplatenses se dedicó fundamentalmente a sus asuntos interiores en ese lustro, con autonomía del resto. Pero existía una tensión latente en la Provincia Oriental, llamada "Cisplatina" por los portugueses que la habían ocupado militarmente entre 1816 y 1820 (y que en numerosos documentos seguía siendo llamada "Banda Oriental", como en tiempos virreinales, por gente que estaba dentro y fuera de ese territorio ubicado al este del río Uruguay). 3

En septiembre de 1822 Brasil se independizó de Portugal y se transformó en un imperio cuyo monarca fue Don Pedro, el hijo del rey portugués João VI. El cambio no fue pacífico, ya que hubo focos de resistencia en Pará, Maranhão, Bahia y también en la Cisplatina, donde quienes proclamaron su fidelidad portuguesa se hicieron fuertes en Montevideo, mientras que en la campaña primaron los independentistas, conducidos por el general Carlos Lecor, quien había dirigido la campaña contra José Artigas de 1816-1820. En ese contexto el cabildo montevideano solicitó auxilio

\footnotetext{
3 En este artículo, se habla de "orientales" al referirse a los oriundos de la Provincia Oriental. Para el uso del término a lo largo del tiempo, así como el nombre del territorio que hoy forma Uruguay, véanse FREGA, Ana: "Uruguayos y orientales: itinerario de una síntesis compleja", José Carlos CHIARAMONTE, Carlos MARICHAL y Aimer GRANADOS (comps.), Crear la nación. Los nombres de los países de América Latina, Buenos Aires, Sudamericana, 2008; ISLAS, Ariadna: "Límites para un Estado. Notas controversiales sobre las lecturas nacionalistas de la Convención Preliminar de Paz de 1828", en Ana FREGA (coord.), Historia regional e independencia del Uruguay. Proceso histórico y revisión crítica de sus relatos, Montevideo, Ediciones de la Banda Oriental, 2009.
} 
económico a Buenos Aires -con el horizonte de volver a sumarse a la provincias rioplatenses-, pero el gobernador Martín Rodríguez y el ministro Bernardino Rivadavia conducían un proyecto político de estabilidad provincial y crecimiento económico que no querían arriesgar yendo otra vez a la guerra, con lo cual decidieron realizar una protesta formal y no pasar a la acción, a pesar de las exigencias de los opositores en la legislatura porteña, quienes percibían una oportunidad para recuperar el territorio oriental, al que consideraban "parte integrante de las provincias". La prescindencia facilitó el triunfo de Lecor, quien en febrero de 1824 tomó Montevideo y afianzó el poder del imperio. 4

Aun así, muchos rioplatenses consideraban que un conflicto por el territorio oriental sería inevitable tarde o temprano, y esa fue una de las razones por las que se convocó a un congreso constituyente para reunir a las provincias, que empezó a sesionar en Buenos Aires a fines de 1824. Lo impulsó un sector de la dirigencia porteña que se creía en condiciones de volver a conducir una organización general, necesaria además por la presión de Gran Bretaña, que estaba dispuesta a reconocer la independencia si se concretaba una unión. 5

Una de las primeras cosas quehizo el Congreso, en marzo de 1825, fue discutir la creación de un ejército. Ya cuando se envió un grupo de soldados para reforzar a Salta contra los realistas altoperuanos el tema pasó a primer plano: esa fuerza, ċera “nacional o de provincia?”6 El diputado porteño Julián Segundo de Agüero, uno de los líderes de la bancada mayoritaria, la que se autodenominada "nacional" y sería llamada "unitaria" por sus enemigos -a causa de su impulso de una soberanía única, aseguró que una nación no podía existir si no tenía un ejército nacional. Pero el jujeño y también unitario Juan Ignacio Gorriti sostuvo que era al revés: no podía

\footnotetext{
4 Puede verse el debate en el Diario de sesiones de la Honorable Junta de Representantes de la Provincia de Buenos Aires, 12 de noviembre de 1823, pp. 484 y ss. De allí es la cita.

5 Para una síntesis de este proceso véase TERNAVASIO, Marcela: "Las reformas rivadavianas en Buenos Aires y el Congreso General Constituyente (1820-1827)", en Noemí GOLDMAN (dir.) Nueva Historia Argentina, vol 3, Buenos Aires, Sudamericana, 1998, p. 131 y ss.

${ }^{6}$ RAVIGNANI, Emilio (comp.), Asambleas Constituyentes Argentinas, Instituto de Investigaciones Históricas de la Facultad de Filosofía y Letras, Tomo I, Buenos Aires, 1937, p. 1257, 19 de abril de 1825.
} 
haber ejército nacional si antes no había nación. Y no era el caso: “¿Cuándo se ha formado la nación señores? ¿Cuándo se constituyó? ¿Cuándo se aceptó la constitución? ¿Cuándo se puso en práctica?”. Hubo diputados que señalaron que aun sin una constitución la nación existía en base a un pacto, como probaba la voluntad de los pueblos de convocar al congreso o como marcaba la declaración de la independencia en 1816 (el salteño Manuel Castro dijo que aquel 9 de julio se creó la nación). ${ }^{7}$

En el mismo momento en que se daba el debate, un pequeño grupo de "33 orientales" comandado por Juan Antonio Lavalleja, quien había sido uno de los lugartenientes de Artigas, partió sigilosamente de Buenos Aires y desembarcó en territorio oriental el 19 de abril de 1825 para promover un levantamiento contra los brasileños. La repercusión de su llegada fue grande y se convirtió en una amenaza para los imperiales cuando Fructuoso Rivera, otro ex artiguista que ahora integraba el ejército portugués, se plegó con sus hombres al movimiento. Rivera era comandante militar de las milicias de la campaña y jefe de los dragones, y eso -junto con la popularidad de la que gozaban ambos líderes- les permitió disponer rápidamente de una fuerza numerosa: entre mayo y noviembre de 1825 habían movilizado a más de 2100 soldados de línea, más unos 1100 milicianos. ${ }^{8}$

\footnotetext{
7 Véase sobre esto WASSERMAN, Fabio, "Revolución y nación en el Río de la Plata (1810-1860)", AAVV, La construcción de la nación argentina. El rol de las fuerzas armadas, Buenos Aires, Ministerio de Defensa, 2010, pp. 38-39. Los debates en Asambleas Constituyentes Argentinas, Tomo I, cit.; lo de Castro en p. 1363.

${ }^{8}$ Los de línea eran los dragones, más nuevos cuerpos de húsares y de libertos. El número fue establecido siguiendo las listas de revista por LUFT, Marcos Vinícios, "Essa guerra desgraçada": recrutamento militar para a Guerra da Cisplatina (1825-1828), tesis de maestría, Universidade Federal do Rio Grande do Sul, Porto Alegre, 2013, p. 173. Un documento llamado "Demostración de las fuerzas tanto patrias como brasileras...”, fechado el 5 de julio de 1825, AGN/A, X, 7-10-4, aseguraba que había en la Provincia Oriental 3230 hombres disciplinados, armados y con caballos suficientes, entre milicianos y veteranos, divididos así: 1200 hombres en el cuartel de Barra de Pintado, sobre todo milicianos "pero con una organización regular", una columna de 1000 compuesta por el regimiento de dragones de la unión y de guerrilleros ("soldados viejos") al mando de Rivera en el paso del Durazno, un "cuerpo ligero" de unos 300 veteranos y milicianos mandados por Manuel Oribe en torno de Montevideo, unos 350 provenientes de "compañías escogidas" de la milicia de campaña del departamento de Maldonado, rodeando Colonia al mando de Leonardo Olivera, una fuerza de 180 en el Paso del Rey sobre el Yi al mando de Ignacio Oribe y 200 hombres más en el Chuy al mando de Pablo Pérez. Para antecedentes de las fuerzas orientales en la década previa véanse los
} 
En las Provincias Unidas, todavía no involucradas de modo directo, la formación de una fuerza sería más lenta. El 9 de mayo de 1825, el nuevo gobernador porteño Gregorio de Las Heras, a cargo del Poder Ejecutivo Nacional hasta que se designase uno, solicitó al Congreso cuidar la línea del río Uruguay para "proveer a la seguridad del país por la guerra que se ha encendido en la Banda Oriental del Río de la Plata". Los diputados de la comisión militar recomendaron pedir a las provincias que enviasen sus cuerpos de línea y organizasen una recluta, ya que los eventos podían "extender su influencia a todo el país". Veinte días después se aprobó por ley la formación del ejército, que debía contar con 7600 hombres. Su base serían unidades previas: los restos del Regimiento Río de la Plata, integrado sobre todo por negros porteños que hicieron la campaña de San Martín en el Perú y permanecieron allí hasta 1824, las tropas que pertenecieron al ejército auxiliar del Perú hasta 1820 y se encontraban en Córdoba, y el batallón de cazadores creado en 1824 en Salta para luchar contra los realistas. 9

Un problema central eran los recursos. Ya antes del estallido oriental, el diputado Lucio Mansilla advirtió que "El gobierno nacional, o la nación, no tiene capitales, de que poder disponer", mientras "que el Gobierno de Buenos Aires dispone de cantidades crecidas". Ciertamente, solo Buenos Aires podía financiar una guerra. $\mathrm{Y}$ de hecho en los meses siguientes serían las arcas porteñas las que enviarían la mayoría del dinero para las compras de carne, arroz, tabaco negro, jabón, ollas, "medicinas", caballos y carretas. Más adelante se creó en la ciudad una "factoría" de textiles para vestir a las tropas. Y por supuesto habría que pagar los sueldos, que se llevaban una gran parte del erario. ${ }^{10}$

trabajos reunidos en FREGA, Ana (coord.) Los orientales en armas: estudios sobre la experiencia militar en la revolución artiguista, Montevideo, CSIC, 2015.

9 El plan era crear un batallón de artillería, cuatro de infantería y seis regimientos de caballería. Asambleas Constituyentes Argentinas, Tomo I, cit., pp. 1353 y 1354. Hubo largos debates. La aprobación final en p. 1396.

${ }^{10}$ Las compras de los utensilios pueblan los legajos del ejército en el AGN/A que se citan a lo largo de este artículo. El decreto de creación de la factoría fue posterior, del 5 de julio de 1826, en AGN/A, 227-2. Respecto de los sueldos, se puede tomar a los granaderos a caballo como índice: los sargentos de tropas veteranas ganaban tres pesos semanales, los clarines y los cabos dos, los granaderos doce reales, es decir un peso y medio. AGN/A, X, 22-5-8, escuadrón de granaderos a caballo, 93, 24 de diciembre de 1825, Villa del Uruguay. 
Para evitar dificultades políticas, la comisión militar aclaró en su proyecto de ley del 11 de mayo de 1825 que "El jefe, o jefes, bajo cuya dirección ponga esta fuerza el poder ejecutivo, no tendrán la menor intervención en el régimen interior de la provincia de Entre Ríos, o de otra donde pudiera acantonarse". ${ }^{11}$ Mansilla, integrante de la comisión, aseguró que un ejército nacional nunca podría sojuzgar a las provincias porque estaría formado por soldados provenientes de ellas, y además iba a ser comandado por el Poder Ejecutivo que sería elegido por el Congreso, en el cual todas estaban representadas. ${ }^{12}$ Pero todos sabían que era posible que se asociara al ejército nacional con los intereses porteños, y que no sería fácil manejar "el estado de rivalidad en que se hallan los de unas provincias con los de otras". ${ }^{13}$

En julio de 1825 se nombró a Martín Rodríguez como general en jefe del ejército "de observación”. El Congreso acordó que el Poder Ejecutivo designara a los rangos superiores y que los oficiales de teniente coronel para abajo respondiesen a las provincias, ya que si no sería imposible conducir los contingentes de tropas desde cada una de ellas. Cada provincia tendría que proporcionar el 1,33\% de su población, y de acuerdo con el censo que se tomó de índice Buenos Aires aportaría 1600 hombres, Córdoba 1200, Santiago 800, Tucumán, Salta y Corrientes 533, Entre Ríos y Catamarca 400, Mendoza, San Juan y San Luis 355, La Rioja 333, Santa Fe 200. ${ }^{14}$ Pero la concreción del plan sería muy difícil.

\section{"El Ejército no tenía fondos"}

Los problemas fueron inmediatos: en agosto de 1825, el jefe de los coraceros -el general Juan Lavalle- informó que desde que la tropa supo que "está destinada al Entre Ríos, una parte de ella no habla de otra cosa que de desertar" y de "volver a sus hogares" (algunos lo hicieron y a otros los apresó hasta que se embarcaran para evitarlo). ${ }^{15}$ Ese mismo mes partieron en el primer contingente porteño, en total 600

\footnotetext{
${ }^{11}$ Asambleas Constituyentes Argentinas, Tomo I, cit., p. 1355.

12 Ibid, p. 1333.

${ }_{13}$ AGN/A, X, 4-4-7, instrucciones al general en jefe del ejército, 27 de julio de 1825.

14 BEVERINA, Juan, La guerra contra el imperio del Brasil, Biblioteca del Oficial, Buenos Aires, 1927, p. 120.

15 AGN/A, X, 4-4-7, 20 de agosto de 1825.
} 
hombres y el propio Martín Rodríguez. La salida de San Nicolás de los Arroyos fue lenta por falta de barcos y luego en Paraná los malos vientos impidieron la llegada de los retrasados. Debían marchar hacia la zona de Concepción del Uruguay, al este de la provincia, pero Rodríguez advertía que "varios rumores esparcidos hacían creer que, en general, no había las mejores disposiciones en el $2^{\circ}$ departamento con respecto al recibimiento a las tropas de Buenos Aires". Sin embargo, el comandante del Uruguay, Ricardo López Jordán, le garantizó su apoyo a Rodríguez y este partió hacia la otra costa, donde a fines de septiembre las tropas construyeron las barracas del campamento para el ejército en Arroyo del Molino. ${ }^{16}$

La vecina Corrientes aprontó 300 dragones, pero hubo suma tirantez acerca de qué hacer con ellos. El gobernador Pedro Ferré pidió armamento y aseguró que para que sus tropas se incorporasen al ejército nacional necesitaba plata para sueldos y alimentos. Rodríguez respondió que hasta que no se pusieran bajo sus órdenes seguían siendo provinciales y no las pagaba la nación. Ferré dijo que la provincia estaba expuesta en su frontera y por lo tanto retrasaba el desplazamiento. Rodríguez contestó que era atribución suya definir cómo organizar y armar las tropas, que era potestad nacional y no de los intereses locales. ${ }^{17}$ Finalmente, el 27 de octubre de 1825 se informó que "los 300 dragones acantonados en Curuzú Cuatiá hicieron el día 20 un movimiento tumultuario, quedando reducidos al número de 150, por la repugnancia que tenían de separarse de su territorio". ${ }^{18} \mathrm{El}$ resto terminó por incorporarse al campamento, donde ya se habían sumado unos 200 entrerrianos, y en noviembre se agregó un contingente de 71 santafesinos. ${ }^{19}$ Así el ejército empezó a existir.

\footnotetext{
${ }_{16}$ AGN/A, X, 4-4-7, cartas de Rodríguez del 20 de agosto y 27 de septiembre de 1825. Las barracas en ROJAS, Manuel, "Memoria”, Revista Nacional, Año III, Tomo VII, $\mathrm{n}^{0}$ 34, Buenos Aires, 1889, p. 337. ${ }_{17}$ Cartas de Ferré y Rodríguez entre el 16 y el 20 de septiembre de 1825, AGN/A, X, 4-4-7. En nota del 12 de octubre se anuncia la llegada de los correntinos al campamento.

${ }_{18}$ Nota de Rodríguez, 27 de octubre de 1827, en AGN/A, X, 4-4-7.

19 El número de entrerrianos lo da IRIARTE, Tomás de, Memorias, vol. 3, Buenos Aires, Sociedad Impresora Americana, 1945, p. 251. El contingente santafesino en AGN/A, X, 4-5-1, 15 de noviembre de 1825 ( 5 desertaron en el camino).
} 
Mientras esto ocurría, los acontecimientos se habían acelerado del otro lado del río Uruguay. En agosto de 1825 los insurgentes se reunieron en un congreso que declaró la independencia respecto del Brasil, nombró a Lavalleja gobernador y solicitó la incorporación a las Provincias Unidas del Río de la Plata. En Buenos Aires, ni Las Heras ni su ministro Manuel García querían la guerra, pero otros de los miembros de su partido, como Rivadavia y Agüero, parecían ahora verla con buenos ojos, como un modo de unir a las provincias detrás de su proyecto centralista. Por su parte, el partido federal presionaba para que se declarara: "pidamos auxilios para los orientales; y pidamos la guerra contra el usurpador del territorio del estado”. ${ }^{20}$ Las dudas fueron despejadas por los triunfos de los rebeldes: en septiembre obtuvieron su primera victoria de envergadura en Rincón, conducidos por Rivera, y en octubre el importante triunfo de Sarandí, liderados por Lavalleja, "que ha dejado a la Banda Oriental libre de opresores". ${ }^{21}$ Efectivamente, tras Sarandí los orientales quedaron dueños de toda la campaña, obligando a los brasileños a refugiarse en Montevideo y Colonia, y a retirar el resto de sus tropas a Rio Grande do Sul. El 25 de octubre el Congreso aceptó a la Provincia Oriental y a su primer diputado. La guerra ya era un hecho y la declaración por parte del Imperio llegó en diciembre.

Sin embargo, el ejército tardaría mucho en estar preparado. Por un lado, porque "su número disminuía de día en día a causa de la deserción continua que se experimenta”. ${ }^{22}$ Además, el general Rodríguez sentía que se encontraba en territorio hostil y apenas un mes después de establecer el campamento propuso cruzar el río Uruguay para reubicarse. "La deserción es aquí protegida por todas las autoridades", decía, al tiempo que ni las recompensas materiales ofrecidas por el ejército ni las amenazas de la pena de muerte habían dado resultado para detener la deserción o para recuperar a los que se habían ido. Y a pesar de la "extremada indigencia de estas gentes" no conseguían atraer voluntarios a las filas; solo tres lo habían hecho y se habían fugado tras cobrar el enganche. A la vez, los dueños del ganado habían subido

\footnotetext{
${ }^{20}$ El Argentino, ${ }^{\circ}$ 9, T. II, 20 de agosto de 1825, p. 111 (era el periódico de los federales porteños).

${ }^{21}$ La expresión es de una carta de Rivera (que también combatió en Sarandí) a Martín Rodríguez, fechada en el Río Negro el 22 de octubre de 1825. AGN/A, X, 4-4-7.

${ }^{22}$ AGN/A, X, 4-5-1, Martín Rodríguez, el 9 de noviembre de 1825.
} 
los precios de la carne, y Rodríguez consideraba que esta era más abundante y barata en la Provincia Oriental. ${ }^{23}$ Su secretario militar escribió que como el ejército pagaba los caballos huidos que estaban marcados, los "gauchos" entrerrianos los espantaban de noche para luego recapturarlos y cobrar la recompensa. ${ }^{24}$

A la vez, la presencia de soldados atraía a los vivanderos, que les vendían de todo. En las instrucciones que recibió Rodríguez se le pedía que fuera duro con su presencia, castigando a los que estimularan la embriaguez de los hombres. También se le encargaba vigilar a la otra compañía de los soldados: las mujeres que viajaban con ellos o las que se acercaban al campamento. "Se le recomienda estrechamente la atención que debe poner en no permitir la permanencia de mujeres corrompidas, y con particularidad de las chinas de Misiones", le advirtieron, "pues es sabido por la experiencia los estragos que aquellas hacen en los ejércitos y que las últimas en diferentes ocasiones han destruido cuerpos enteros". ${ }^{25}$ De hecho, cuando hacia fin de año Rodríguez empezó a ser presionado para que el ejército pasara a la Provincia Oriental, el general parecía haber cambiado de opinión y puso a la cuestión de las mujeres como la dificultad central.

"Es en mi concepto uno de los inconvenientes no pequeños que presenta para marchar a primera orden, y estar listo al efecto como lo desea el gobierno ejecutivo según usted me lo previene en su comunicación del 21 anterior, el crecido número de mujeres casadas con hijos de todas las edades que existen en la línea y han venido con las tropas de los contingentes de las provincias; siendo muy notable que hayan sido los primeros en dar este ejemplo perjudicial los escuadrones de Húsares y Coraceros que vinieron del Salto con consentimiento del jefe general de ellos, según lo aseguran los oficiales todos por quienes se ha presentado una lista de revista de aquellas, para conocer que eran asistidas con raciones lo mismo que al soldado, y aun también con gratificación por cada una e hijos: en ese estado se reunieron en el Paraná; y ya no me fue posible tomar la medida de separarlas, por evitar consecuencias de trascendencia

23 AGN/A, X, 4-5-1, oficio del 18 de noviembre de 1825. El ejército comunicaba al gobierno periódicamente los desertores de los distintos cuerpos, con nombre y apellido; en general se trataba de soldados y clarines, los rangos más bajos. Hay varios documentos en AGN/A, X, 4-5-1, firmados por Manuel Rojas.

24 IRIARTE, ob. cit., p. 252. El panorama que presenta en sus memorias de pobreza de Entre Ríos y de problemas del ejército coincide plenamente con los informes de Rodríguez.

25 AGN/A, X, 4-4-7, 27 de julio de 1825. 
que debía temerse, si se hubiera hecho regresar a San Nicolás: así han marchado hasta aquí proveyéndolas con la mantención únicamente, mas aumentándose considerablemente esta clase de mujeres con la tropa que se hallaba en el campamento de Entre Ríos, y la que se ha incorporado últimamente de Santa Fe, es llegado el momento de pedir al Gobierno Nacional una resolución terminante que me ponga a salvo de los resultados, que pueda traer cualquiera que se adopte: los gastos que son consiguientes debe originar al Ejército en mantención y la de sus hijos; los caballos en que deben transportarse; y las distracciones que ellas causan al soldado haciéndolo faltar a sus obligaciones para asistirlas y cuidarlas, como es natural, no pueden ocultarse al conocimiento de V.E.: este negocio presenta por otra parte la dificultad, que separadas aquellas debe esperarse que deserten muchos por reunírseles, y esta ha sido la única razón que he tenido en vista para no haberlo ya ordenado, como lo he hecho con las que no eran mujeres propias, por mantener la buena policía del Ejército". ${ }^{26}$

El ministro de guerra respondió que viera “el modo mejor de deshacerse de ellas".

El otro problema era que la llegada de los contingentes provinciales se cumplía lenta y dificultosamente. El peso de las levas, el desinterés en la guerra particularmente fuerte en aquellos que procedían de zonas lejanas al área de conflicto- y la indignación generada por los abusos de las partidas reclutadoras provocaron rápidamente algo usual en los ejércitos de la época: altas tasas de deserción. Por ejemplo, los cazadores de Salta perdieron alrededor del 30\% de sus soldados en la marcha hacia el Litoral a fines de $1825 \cdot{ }^{27}$ Las columnas se sumaban reducidas al ejército, muchos hombres "llegaban al campamento con esposas y grillos”, y las deserciones también eran numerosas allí. ${ }^{28}$ Otros nunca arribaron: Santiago del Estero no envió a nadie, por falta de fondos y porque temía "una invasión de los bárbaros”, al tiempo que el gobernador de Misiones comunicó que

\footnotetext{
${ }^{26}$ Rodríguez el 26 de noviembre de 1825, en AGN/A, X, 4-5-1.

27 RABINOVICH, Alejandro, "El fenómeno de la deserción en las guerras de la revolución e independencia del Río de la Plata: 1810-1829” E.I.A.L., vol. 2, nº 1, 2011. La información proviene de los diarios de Paz y Todd.

28 ROJAS, ob. cit., p. 337.
} 
no mandaba hombres porque los "portugueses" estaban en la provincia quemando ranchos. ${ }^{29}$

De todos modos, al empezar el nuevo año se le exigió a Rodríguez abrir la campaña. El general, furioso, comentó a Lavalleja que "el gobierno sabía muy bien que la fuerza que lo compone es por la mayor parte de reclutas, hombres forzados y por consiguiente descontentos". No podía armarlos porque de las 1381 carabinas que le enviaron solo 94 servían. Además, "el Gobierno sabía que no habiendo destinado al Ejército generales, jefes y oficiales de instrucción ésta no podía perfeccionarse, sabía que el Ejército no tenía fondos para efectuar un tal movimiento, mucho menos para la compra tan necesaria de caballos, y ni aun para pagar el haber del soldado que viene de provincias remotas con el afán de obtenerlo mensualmente", al punto que él mismo "se ha visto constituido (y se ve) a ofrecer la garantía de su firma para obtener de algunos particulares a fin de subvenir a las primeras necesidades de la fuerza que tiene a sus órdenes". No podía entonces avanzar y menos en el momento en que acababan de llegar "más de 1000 reclutas de las provincias de Córdoba, Mendoza, San Juan y Misiones es decir más de la mitad de la fuerza existente!!”30 Rodríguez aseguraba que no renunciaba porque la situación era grave. Su descripción, exagerada o no, mostraba que el ejército era todavía más proyecto que realidad.

Aun así, a fin de enero de 1826 la fuerza hizo el cruce y se instaló en la Provincia Oriental. Pero la situación no mejoró y al terminar marzo Rodríguez comunicó al gobierno que contaba solo con 2800 hombres, con una instrucción deficiente. ${ }^{31}$ El número estaba muy por debajo del que había pensado el Congreso, si

\footnotetext{
29 Respectivamente: para Santiago cartas de Gregorio Araóz de Lamadrid el 19 de septiembre de 1825 y de José María Paz el 29 de enero de 1826; para Misiones nota de Félix Aguirre, 4 de noviembre de 1825; las tres en AGN/A, X, 4-4-7.

30 AGN/U, Archivo del ejército, caja 352, carpeta 1, 5. Nota de Rodríguez en el cuartel general del Arroyo del Molino el 2 de enero de 1826. El 24 de noviembre se informaba en San Nicolás la partida de buques que llevaban a 604 cordobeses y cuyanos. AGN/A, X, 4-5-1, firma el comisario José María González. En una "noticia" del 20 de diciembre de 1825 detalló que en total entraron 1213 soldados de esos contingentes, AGN/A, 4-5-1.

${ }^{31}$ BALDRICH, Juan Amadeo, Historia de la guerra del Brasil, Buenos Aires, Eudeba, $1974\left(1^{\circ}\right.$ ed. 1905), p. 75 .
} 
bien faltaba la integración con las tropas orientales. Pero ambas fuerzas unidas no alcanzaban para luchar exitosamente contra los imperiales, porque además unos cuantos combatientes debían quedarse a mantener los sitios de Colonia y Montevideo. Era necesario entonces conseguir más hombres.

Un puesto de soldado representaba un salario en teoría estable, además de un vestuario en una sociedad no industrializada donde la ropa era cara, pero los recuerdos de años de guerra mostraban que ese sueldo militar se atrasaba crónicamente, y por lo tanto conseguir voluntarios se hizo muy difícil. En Córdoba, por caso, los reclutadores decían que a sus llamados de voluntarios solo respondía el silencio..$^{2} \mathrm{El}$ "rescate" de esclavos para el ejército, que fue clave en la guerra de la independencia, parece haber sido un poco más limitado esta vez, al menos en Buenos Aires. Ello se dio sobre todo porque la esclavitud estaba disminuyendo debido a que no había más tráfico desde 1812, no nacían nuevos esclavos desde la sanción de la libertad de vientres de 1813 y varios varones habían llegado a la libertad a través de ser soldados en la guerra previa. El grueso del reclutamiento para integrar las filas se hizo entonces de modo forzoso, recayendo sobre quienes eran llamados "vagos" por las autoridades, es decir los trabajadores humildes. 33

\section{"Las ideas de Don José Artigas"}

Las acciones de los soldados contra los malos tratos y las penurias económicas fueron muchas durante 1826, al compás de las levas o de su llegada a unirse al ejército. Ya en enero el encargado de las baterías de Punta Gorda (Diamante), sobre el Paraná, avisó que los soldados no habían querido trabajar porque no les habían pagado su sueldo, y pidió se les abonase con urgencia ya que existía un "estado de sublevación". 34 Era solo el preludio: el 15 de febrero de 1826 informó que "los

\footnotetext{
$3^{2}$ MEISEL, Seth, "The Politics of Seduction: Mutiny and Desertion in Early Nineteenth-Century Cordoba”, Jane HATHAWAY, Rebellion, Repression, Reinvention: Mutiny in Comparative Perspective, Westport, Praeger, 2001, p. 138.

33 Véanse al respecto FRADKIN, Raúl, La Historia de una montonera. Bandolerismo y caudillismo en Buenos Aires, 1826, Siglo XXI, Buenos Aires, 2006; DI MEGLIO, iViva el bajo pueblo! La plebe urbana de Buenos Aires y la política entre la Revolución de Mayo y el rosismo, Buenos Aires, Prometeo Libros, 2006.

34 José León Domínguez el 14 de enero de 1826, AGN/A X, 4-4-6.
} 
correntinos se le sublevaron ayer a las 10 de la noche dirigiéndose a su habitación con un vivo fuego, por lo que no pudo si no huir a la Bajada [Paraná] con un lanchón a solicitar auxilios”. Un comisario advirtió que se habían marchado "al Montiel”, al interior de la provincia. 35

Fue un febrero candente. Los reclutas de Salta llegaron a Paraná y de inmediato se amotinaron. Desertaron 199, de los cuales 30 fueron aprehendidos otra vez. ${ }^{6}$ Hubo también una importante deserción en la recluta que llegaba de Mendoza, San Juan y San Luis. ${ }^{77}$ El alférez José María Todd narró en sus memorias que los puntanos -como se conocía a los oriundos de la provincia de San Luis- se sublevaron en la jabonería que les hacía de cuartel en la ciudad, y muchos se marcharon. En los días siguientes algunos volvieron y se les dieron caballos para persuadir al resto (solo los cabecillas, según Todd, no regresaron); un oficial informó que algunos se incorporaron a las filas en marzo. ${ }^{8}$

Pudo haber contagio en estos episodios simultáneos, pero tenían una base común: el comisario Juan Garrigó advirtió a su superior que si "estuviese en el Paraná con mi cargo no tengo duda de que a vista de la infelicidad, desnudez y desesperación de los reclutas que han pasado y pasan haría lo que yo mismo para no exasperarlos enteramente". Para apaciguarlos "voy a darles una ración de jabón, media vara de tabaco con su correspondiente papel, cuatro reales a cada recluta y ocho a cada veterano". 39

La conflictiva situación política de Entre Ríos contribuía también al panorama agitado. En diciembre había sido elegido gobernador López Jordán, representante de la costa del río Uruguay, pero la presión santafesina obligó a la legislatura a

35 Carta de José León Domínguez del 16 de febrero de 1826, AGN/A X, 4-4-6. El segundo testimonio, del mismo legajo, es de una carta del comisario Juan Garrigó el 15 de febrero. La "selva de Montiel" era un espacio donde había poco control estatal.

${ }^{36}$ Nota del 20 de febrero de 1826, en AGN/A, X, 4-4-6.

37 Carta de Juan Garrigó del 21 de febrero de 1826, AGN/A, X, 4-4-6.

${ }_{38}^{8}$ TODD, José María Recuerdos del ejército de operaciones contra el emperador del Brasil, Buenos Aires, Betograf, 1959, pp. 7-8. Y luego nota del teniente coronel Daniel Ferreyra del 4 de marzo de 1826, AGN/A, X, 4-4-6. El caso lo trabajó RABINOVICH en "El fenómeno de la deserción...", ob. cit. 39 Carta de Juan Garrigó del 22 de febrero de 1826, AGN/A, X, 4-4-6. 
cambiar su decisión y devolver el poder a la elite de Paraná. Se creó un virtual estado de guerra civil provincial y en febrero de 1826 se advertía que en Paraná había "una masa de ciudadanos armados que amenazaba la existencia del gobierno".40

Ese mismo mes el gobernador de Misiones comunicó a Rodríguez -quien ya estaba en la Provincia Oriental- que el envío de tropas se atrasó porque tuvo que perseguir a nueve desertores "de los Nacionales", a los que finalmente capturó e incorporó a su contingente. A algunos no los habían podido atrapar sus partidas, pero se entregaron cuando les prometió un indulto. Se disponía luego a marchar "a desbaratar una Compañía que se levantó haciendo el atentado de matar a su capitán, teniente y secretario".41

Asimismo, en ese febrero, hubo un intento de sublevación en una columna de 140 tucumanos y catamarqueños que se puso en marcha hacia el frente; fue liderado por dos soldados, que fueron castigados con cien azotes cada uno. No obstante, cuando llegaron en abril a San Nicolás de los Arroyos se habían fugado 41 hombres. ${ }^{42}$ Y casi en simultáneo muchos soldados desertaron de una unidad en la Provincia Oriental, en la que "toda la compañía se iba a dispersar porque no quería estar a las órdenes del capitán D. Juan José Martínez”.43 Y también comenzó la deserción en la división oriental que estaba apostada en San José.44

Los desertores podían conseguir protección en establecimientos que necesitaban mano de obra. En Buenos Aires, por ejemplo, se denunció a una panadería y una fábrica de fideos donde había varios, y un comerciante fue enviado a prisión por ocultar a dos artilleros. 45 También podían obtenerla por el rencor con

40 Carta de José León Domínguez del 24 de febrero de 1826, AGN/A, X, 4-4-6. Véase SCHMIT, Roberto, Ruina y resurrección en tiempos de guerra: sociedad, economía y poder en el oriente entrerriano posrevolucionario, 1810-1852, Buenos Aires, Prometeo Libros, 2004, p. 166 y ss.

${ }^{41}$ Félix de Aguirre, 22 de febrero de 1826, Paso del Rosario. Boletín Histórico, ${ }^{0}$ 39, Montevideo, 1949, p. 59. Su contingente tenía 61 soldados.

42 AGN/A, X, 4-4-5, nota de Ramón Rodríguez, 4 de abril de 1826.

43 No indica de qué cuerpo se trata. AGN/U, Archivo del ejército, caja 352, carpeta 1, 3, 1826.

44 Gregorio Planes a Lavalleja, 18 de junio de 1826, Boletín Histórico, nº 37, Montevideo, 1949, p. 81.

45 Respectivamente AGN/A, X, 14-2-1, 10 de mayo de 1826 (nota del ministro de guerra); AGN/A, X, 4-4-7, julio de 1825. El comerciante se llamaba Custodio Moreira. En ambos casos eran desertores de la escuadra. 
la leva. A un enviado en misión secreta al Interior se le recomendó que "luego que saliese del territorio de la provincia de Buenos Aires hiciese entender a la gente de la campaña por donde transitase que era desertor de las tropas de Buenos Aires, que se iba para su tierra, y que con esta estratagema podría fácilmente llegar a su destino en razón de que los Pueblos comparaban [amparaban] los desertores". ${ }^{6}$ Asimismo, había solidaridades entre soldados. Uno de ellos fue interrogado sobre por qué no denunció a un cabo que quiso convencerlo de desertar, a lo que contestó que no lo hizo, "considerándolo un hombre como él y que le era sensible ver castigar a nadie.” 47

El ejército destinó hombres a perseguirlos y aplicó penas duras. Desde que en noviembre de 1825 se fusiló a seis desertores en el campamento de Arroyo del Molino, ese tipo de sanciones se repitió. ${ }^{8}$ Los diarios y memorias de varios oficiales a lo largo de 1826 destacan los continuos fusilamientos y azotes aplicados a los desertores en los sucesivos campamentos del ejército.49 Iriarte consignó que el cuerpo de artilleros a su mando, "gente forzada que estaba muy descontenta con la vida militar", quiso rebelarse dirigido por un sargento, y él hizo castigar a los líderes a palazos. $5^{\circ}$

Por su parte, el ministerio de guerra en Buenos Aires comenzó a hacer "relaciones de desertores cuyo reemplazo hay que reclamar" a cada provincia. ${ }^{11} \mathrm{En}$ mayo, el gobierno nacional decretó que como el enganche voluntario no funcionaba, ya que no aportaba la gente suficiente y contribuía "a la inmoralidad fomentando la disposición a la deserción", quienes se alistaran cobrarían su dinero una vez terminado el servicio. ${ }^{52}$ Evidentemente una medida tal no generó una mayor

\footnotetext{
46 AGN/A, X, 29-11-5, Sumarios Militares, 369.

47 Sumario contra el cabo Eustaquio Baigorria, de la escolta del gobierno (1826). AGN/A, X, 29-9-9, Sumarios Militares, 86.

48 AGN/A, X, 4-5-1, nota del 15 de noviembre de 1825.

49 PAZ, José María, Memorias póstumas, T. II, Buenos Aires, Ediciones Estrada, 1957, p. 441; BRITO DEL PINO, José, Diario de la guerra del Brasil, Montevideo, 1956, p. 33.

50 IRIARTE, ob. cit., pp. 325-333. Hubo varios motines y deserciones en la escuadra del Almirante Brown, que luchó contra el bloqueo. Véase el capítulo 6 de DI MEGLIO, Gabriel, iViva el bajo pueblo!, ob. cit.

${ }^{11}$ Véase AGN/A, X, 4-4-6.

$5^{2}$ AGN/A, 14-2-1, 11 de mayo de 1826 (decreto presidencial comunicado por el ministro de guerra).
} 
cantidad de voluntarios para un ejército que seguía necesitando hombres. La única solución posible era intensificar el reclutamiento forzoso y eso fue lo que hizo el gobierno nacional a lo largo de 1826, fundamentalmente en el espacio que controlaba directamente: Buenos Aires. En la ciudad se reclutaron hombres para la infantería y en la campaña para la caballería, tanto para la lucha contra los brasileños -en la que la provincia aportaría más soldados que los que le tocaban inicialmentecomo la que se libraba con los indígenas, en un contexto de conflictos fuertes en la frontera.

Distintos trabajos han mostrado que la gran leva de 1826 en Buenos Aires fue tan extrema que incluso a los milicianos no se les respetó su condición y muchos de ellos fueron enviados a las tropas de línea, lo cual iba en contra de los usos y la legislación. En agosto, un porteño escribió en su diario que "en la ciudad y su campaña" la leva había causado estragos, ya que al no haberse distinguido "vagos, ni trabajadores, casados, ni solteros, hombres, y niños aun de 12 años, quedaron las madres pobres, y padres ancianos, sin el amparo de sus hijos, particularmente los de la campaña”. 53

A esto se sumó el problema de que el gobierno nacional no tenía la capacidad financiera para sostener los enormes gastos del ejército, situación agravada porque el puerto de Buenos Aires estaba bloqueado por la escuadra naval brasileña desde fines de 1825, lo cual disminuía los ingresos estatales. Como resultado, en febrero de 1826 se disparó fuertemente la inflación del papel moneda. ${ }^{54}$ Estas variables dieron lugar a grandes descontentos en la campaña bonaerense y a la aparición de "partidas de gauchos" y desertores que realizaban robos de ganado (Raúl Fradkin contabilizó 49 gavillas que actuaron en Buenos Aires a lo largo de 1826). E incluso se formaron

53 BERUTI, Juan Manuel, "Memorias curiosas", Biblioteca de Mayo. Colección de obras y documentos para la historia argentina, Buenos Aires, Senado de la Nación, T. IV, 1960, p. 3990 (10 de agosto de 1826). Véanse sobre el tema FRADKIN, Raúl, La Historia de una montonera, ob. cit.; DI MEGLIO, iViva el bajo pueblo!, ob. cit.

$54 \mathrm{Al}$ respecto puede verse HALPERIN DONGHI, Tulio, Guerra y finanzas en los orígenes del estado argentino (1791-1850), Buenos Aires, Editorial de Belgrano, 1982. 
montoneras que se expresaron abiertamente contra las autoridades, como la que atacó Navarro y Luján en diciembre de ese año convulsionado.55

Esa agitación popular fue clave en Buenos Aires para afirmar la popularidad del partido federal, que se oponía a las levas, fustigaba a las autoridades unitarias y las acusaba de "aristócratas". ${ }^{66} \mathrm{En}$ el Litoral, donde la experiencia revolucionaria había sido más radical en la década previa, los descontentos de tropas y paisanos no parecen haber tenido en 1826 expresiones políticas partidarias, sobre todo porque los líderes orientales, y aparentemente también los entrerrianos, evitaron reivindicar la experiencia artiguista en la que habían intervenido, ahora condenada por todos como "anarquía”. 57

Pero ella no se podía borrar por completo. En octubre, Juan Garrigó, comisario de Paraná y miembro de la elite de esa ciudad, avisó que había hecho "esfuerzos por contener algunos excesos que produce una cierta fermentación, que solo el tiempo desvanecerá (si es posible que se desvanezca) por la fuerza del convencimiento". La causa era que "suena aún en los oídos de muchos hombres (de los que nada tienen que perder) las ideas de Don José Artigas, las del finado Don Francisco Ramírez, y las del también finado Eusebio Hereñú"...58

\section{"El orden y la nacionalización"}

Mencionar las ideas de tres referentes de la experiencia revolucionaria de los Pueblos Libres -el Protector y los anteriores líderes del este y el oeste entrerrianosen "los que nada tienen que perder", aludía al igualitarismo y a los reclamos sociales. Sin embargo, ese fenómeno -siempre incómodo para las elites- no parece haber sido

\footnotetext{
55 La cita es de una denuncia en Salto, en una nota del ministro de guerra del 23 de mayo de 1826, AGN/A, X, 14-2-1. Luego FRADKIN, ob. cit. (el número de gavillas en p. 127).

${ }^{56}$ Como expresó su periódico El Tribuno, ${ }^{\circ}$ 1, p. 1,11 de octubre de 1826 . Al respecto véanse DI MEGLIO, Gabriel, Manuel Dorrego. Vida y muerte de un líder popular, Buenos Aires, Edhasa, 2014; y FRADKIN, Raúl; GELMAN, Jorge, Juan Manuel de Rosas. La construcción de un liderazgo político, Buenos aires, Edhasa, 2015.

57 Para la Provincia Oriental véase BARRÁN, José Pedro, "La independencia y el miedo a la revolución social en 1825", Revista de la Biblioteca Nacional. n 24, Montevideo, 1986.

${ }^{8}$ AGN/A, X, 4-4-4, 9 de octubre de 1826.
} 
el rasgo de la antigua "anarquía" que más preocupaba a las autoridades nacionales, sino otro: la tendencia a asegurar la autonomía provincial respecto de cualquier gobierno central, clave desde la década previa, y que chocaba con el proyecto unitario de una nación centralizada. Para conseguirla, los unitarios, que eran mayoría en el Congreso, lanzaron una andanada de medidas desde que empezó 1826: nombraron un presidente para el país -Bernardino Rivadavia- sin todavía haber sancionado una constitución, nacionalizaron a la ciudad de Buenos Aires y avanzaron hacia la sanción de una constitución centralista. En ese marco, el ejército nacional podía ser percibido como un peligro de control externo a las provincias.

Ya se vio que el general Rodríguez tuvo una disputa con el correntino Ferré y que se sintió hostigado en Entre Ríos, culpando a los "principales caudillos y otras personas malévolas de este departamento del Uruguay", un grupo de "anarquistas" que no quería que el ejército estuviese allí.59 Según su colaborador Iriarte, "todavía esta provincia respiraba el espíritu de insubordinación y anarquía, y una fuerte antipatía contra Buenos Aires". ${ }^{60}$ La desconfianza mutua siguió cuando el ejército pasó a la Provincia Oriental: Rodríguez acusó a López Jordán de proteger a desertores de su ejército, pero el comandante lo negó y le respondió airado que no escuchara a quienes "se obstinan en promover la discordia en los momento que el Gobierno Nacional grita iUnión! iFraternidad! iNacionalización!”61

Pero al mismo tiempo ese gobierno renovaba los motivos de suspicacia: en los últimos días de 1825 el Congreso había decidido que Entre Ríos, la Provincia Oriental, Corrientes y Misiones tendrían como "capitán general" al general en jefe del ejército nacional, es decir a Rodríguez. En paralelo, las tropas veteranas y las milicias en todo el país fueron puestas por ley bajo la dirección del Poder Ejecutivo nacional. ${ }^{62} \mathrm{Si}$ alguien quería ver a la elite de Buenos Aires consiguiendo por otros medios lo que no había obtenido en su antigua intendencia -que abarcaba todo el

\footnotetext{
59 AGN/A, X, 4-5-1, oficio del 18 de noviembre de 1825.

6o IRIARTE, ob. cit., p. 246.

${ }^{61}$ Nota del 19 de marzo de 1826, en Boletín Histórico, no ${ }^{0}$ 35, Montevideo, 1948, p. 76

${ }^{62}$ Agüero a Lavalleja, 16 de junio de 1826, Boletín Histórico $\mathrm{n}^{\circ}$ 37, Montevideo, 1949, p. 66 y ss.
} 
Litoral- durante la década previa, no habría podido ser acusado de estar muy errado. De hecho, el nuevo gobernador de Entre Ríos, Vicente Zapata -nombrado en abril de 1826 como un compromiso entre ambas orillas de la provincia-, le escribió a Lavalleja en julio para ofrecerle su amistad y avisarle que se enteró "por unos pasajeros comerciantes" que Rodríguez haría una salida contra el general oriental, aduciendo que este "no ha dado el contingente, pero yo creo que sus miras son destruir a Ud, para luego sojuzgarnos a los inmediatos". Para él, entre entrerrianos y orientales "la causa es común". ${ }^{63}$

Coincidiendo con el pase del ejército a la Provincia Oriental a principios de ese año, comenzó allí un proceso de nacionalización. El 25 de enero, un oficial comunicó que en Santo Domingo Soriano se enarboló “con toda la solemnidad posible el Pabellón Nacional compuesto con las tres fajas horizontales dos celestes y una blanca", pero que poco antes le habían comunicado que debía usarse otra, la de tres franjas, celeste, blanca y punzó (la misma que Otorgués había hecho flamear en Montevideo cuando los artiguistas tomaron la ciudad en 1815), que el nuevo gobierno oriental había decidido utilizar medio año antes "hasta tanto que incorporados los diputados de esta Provincia al Soberano Congreso Nacional se enarbolase el reconocido por el resto de las Provincias Unidas del Río de la Plata”. 64 El oficial le comunicó a Lavalleja que no sabía qué debía hacer. Otro le escribió a Rivera contando que había recibido su orden de elevar la bandera que incluía el rojo, "pero habiendo el Gobierno Delegado, circulado otro decreto posterior de la Honorable Sala, ya flamea en este Departamento el pabellón blanco y celeste de las Provincias Unidas". 65 Y también en las tropas que venían de las distintas provincias se inició el esfuerzo nacionalizador. Por ejemplo, el 5 de mayo se festejó un triunfo

\footnotetext{
${ }_{63}$ Archivo del General Juan A. Lavalleja, T. I, Montevideo, Archivo General de la Nación de la República Oriental del Uruguay, 1935, p. 180.

64 AGN/U, Archivo del ejército, caja 352, carpeta 2, 92, 1826. El oficial era Miguel Planes, en carta a Lavalleja.

65 Juan Arenas a Rivera el 27 de enero de 1826, Boletín Histórico, n 27-28, Montevideo, 1947, p. 13.
} 
de la escuadra naval rioplatense con salvas de artillería y "el grito general de iViva la Nación!”. 66

Más difícil fue para Rodríguez lograr que Lavalleja se le subordinase y se incorporara al ejército con sus fuerzas orientales: "se digne tener presente", le escribió, "que el general infrascrito, no solo lo es en Jefe del Ejército Nacional, si también con el mando de las cuatro Provincias, Misiones, Corrientes, Entre Ríos y la Banda Oriental". ${ }^{67}$ Sin embargo, el gobernador oriental -cuyas fuerzas eran de magnitud similar a las de Rodríguez- demoró tal acción durante meses, y la relación entre ambos se hizo muy tensa. Lavalleja se declaraba ofendido por la desconfianza que le mostraban, defendía el nombre de "ejército oriental" que los nacionales le objetaban a la provincia (“iImpropia esta denominación! ¿Cómo pudo ser cuando no pertenecía más que a sí misma cuando se la dio a su Ejército?”), y se quejaba de que le hicieran mover sus fuerzas, descuidando a la provincia. ${ }^{68}$

Los orientales no se opusieron al gobierno nacional ni se involucraron abiertamente en la disputa entre unidad o federación, pero habían empezado la guerra solos y sus jefes habían luchado contra los gobiernos centrales en la década previa. El recelo era grande de ambos lados. El gobierno nacional estaba "siempre en precaución de los síntomas que prepararon la anarquía desde el año 12 bajo el caudillo Artigas y que trajeron una cadena de desgracias", le advirtió Carlos de Alvear -ministro de guerra, que había sido uno de los protagonistas de aquellos conflictosa Lavalleja en mayo; si todas las tropas no pasaban a estar bajo la égida de Rodríguez, “no puede haber ejército, ni hacerse la guerra, ni organizarse la Nación”. Lo urgía entonces a cumplir las órdenes, "para que de este modo las fuerzas dichas Orientales sean organizadas, vestidas, mantenidas y pagadas como corresponde, y la Nación

66 BRITO DEL PINO, ob. cit., p. 67.

${ }_{67}$ Rodríguez a Lavalleja, 11 de marzo de 1826, Boletín Histórico, ${ }^{0}$ 34, Montevideo, 1948, p. 62. 68 Lavalleja a Rodríguez, 5 de abril de 1826, Boletín Histórico, $\mathrm{n}^{0}$ 35, Montevideo, 1948, pp. 77-78. 
tenga una garantía de que sus sacrificios no serán destinados a renovar la funesta época del caudillo Artigas". ${ }^{69}$

Precisamente la necesidad de auxilios económicos del ejército oriental se volvió un factor decisivo. Agüero, que ahora era ministro de gobierno, aprovechó en junio para intervenir: en sendas cartas presionó tanto a la Junta de Representantes de la Provincia Oriental como directamente a Lavalleja. Les recordó que Rodríguez le había ordenado a aquel "que con todas las fuerzas que tenía acantonadas en el Durazno se preparase a marchar al Queguay, como una medida de la cual pendía la ejecución del plan adoptado para abrir en oportunidad la campaña con suceso". Lavalleja remitió tropas desde Montevideo, Colonia y Cerro Largo, pero sostuvo que no podía enviar las de Durazno, donde tenía su campamento, "porque las necesita para proceder en el mando político de su provincia”. Pero el ministro insistió: era de "indispensable necesidad que en la Provincia Oriental no haya otra autoridad militar que la del General en Jefe del Ejército de la Nación, ni fuerza alguna que a él no pertenezca”, y con tono amenazante emplazó a la Junta a nombrar un gobernador para el manejo administrativo y obligar a Lavalleja a quedar solo con el mando militar, subordinado al general en jefe del ejército. $7^{\circ 0}$ Para asegurar el cumplimiento de las directivas, Agüero envió al experimentado unitario Ignacio Núñez, quien declaró que iba a trabajar por todos los medios para lograr "el orden y la nacionalización”. Tendría trabajo: cuando llegó en junio al Puerto de las Vacas (hoy Carmelo), al que llamó "el más concurrido y el más importante de esta banda”, Núñez informo que había algunas dificultades entre jefes y oficiales, "unos pertenecientes al ejército nacional, y los otros a la provincia”. ${ }^{71}$

Mientras estas negociaciones se llevaban adelante, los dragones orientales acantonados en Durazno se sublevaron el 2 de julio dirigidos por cuatro sargentos,

69 Cit. en SALTERAIN Y HERRERA, Eduardo, Lavalleja. La redención patria, tomo II, Montevideo, Publicaciones de la Comisión Nacional de Homenaje del Sesquicentenario de los Hechos Históricos de 1825, 1975, pp. 21-22.

70 Carta reservada de Agüero a la Junta de Representantes oriental del 26 de junio de 1826, AGN/A, X, 7-10-4. De allí son las citas. La otra es una carta a Lavalleja del 16 de junio. Boletín Histórico, no 37,1949, p. 70 y ss.

${ }^{71}$ Carta de Núñez del 23 de junio de 1826, AGN/A, X, 7-10-4. 
aduciendo que hacía meses que no cobraban su sueldo. Abandonaron el campamento y se dirigieron hacia el de Rodríguez, para sumarse a sus filas. Simultáneamente, Rodríguez, que desconocía el motín, decidió enviar el 4 de julio una división de caballería hacia Durazno "para obligar al general Lavalleja a entregar la fuerza que tiene tantas veces ofrecida y que le ha sido pedidas otras tantas por órdenes reiteradas" (tal como el entrerriano Zapata le avisara a aquel). En su diario, el general José María Paz consignó que "se hace correr en el ejército la voz de que el barón de la Laguna [Lecor] le ofrece un millón de pesos y 9000 bayonetas [a Lavalleja] para sostener la independencia de la Banda Oriental contra el gobierno nacional”, aunque a él no le parecía algo creíble.

Cuando muchos auguraban un conflicto armado, la situación pareció solucionarse: Lavalleja aceptó renunciar al mando político (fue reemplazado por Joaquín Suárez) y se incorporó con sus fuerzas al ejército nacional, que se presentó en Durazno. En el resultado parecen haber jugado varios factores, además de la obvia necesidad de llegar a un acuerdo para poder luchar contra los imperiales: la misión de Núñez ante la Junta de Representantes, la negativa de varios oficiales a entrar en un conflicto entre rioplatenses, y el hecho de que el avenimiento se dio en el mismo momento en que el gobierno nacional decidiera reemplazar a Rodríguez por Alvear como general en jefe del ejército. También tuvo un papel la rivalidad entre Lavalleja y Fructuoso Rivera. Este había dejado el ejército oriental para sumarse al nacional un tiempo antes y corrió el rumor de que los dragones amotinados le respondían (el general Paz sostuvo que las autoridades buscaban "servirse diestramente de su enemistad, y sacar partido de su doble influencia en la provincia”). 72

Los dragones fueron indultados para que entrasen al ejército, pero se decidió distribuir a cien de ellos en distintos cuerpos militares. Al enterarse, Rivera reaccionó con furia y abandonó el ejército, pasando a Buenos Aires. La situación estaba superada y Núñez comunicó a Agüero que "el general Lavalleja va acreditando

\footnotetext{
$7^{2}$ Las citas son del diario de PAZ, ob. cit., pp. 424 y 429. Véanse también SALTERAIN Y HERRERA, ob. cit., y BEVERINA, ob. cit. Sobre las posiciones cambiantes de Lavalleja y Rivera véase el importante libro REAL DE AZÚA, Carlos, Los orígenes de la nacionalidad uruguaya, Montevideo, Arca, 1990. pp. 322-336.
} 
en la práctica que es susceptible de una comportación menos alarmante de la que se ha observado hasta aquí, con solo tener una dirección sana”.73

El ejército empezó a reorganizarse: mientras se armaban los regimientos, un oficial anotó que "se piensa en un arreglo que confunda o mezcle los soldados de todas las provincias, para desarraigar así ese espíritu de localidad que tantas veces se ha hecho sentir". ${ }^{74}$ Pero los dragones orientales no aceptaron su disolución y se amotinaron dirigidos por el hermano de Fructuoso Rivera, Bernabé, quien se quejaba de que a sus oficiales, "héroes de Rincón y Sarandí, los vemos en el Durazno sin colocación y haciendo un papel el más triste”. Lavalleja fue a negociar con los rebeldes, pero no tuvo éxito.75 Otros oficiales en distintos puntos se expresaron a favor del levantamiento (incluyendo a un grupo de "indios charrúas"), y una partida saqueó el equipaje del general Rodríguez, quien partía hacia Buenos Aires. El comandante José María Raña, enterado de que iban a "desarmar al Regimiento de Milicias de Entre Ríos que tengo el honor de mandar, y no encontrando motivo alguno para que se diera un paso tan injusto, me puse en marcha con los 328 hombres que lo componen", para sumarse a los sublevados, exigiendo que les pusieran como jefe a Fructuoso Rivera. Los oficiales temían qué podía ocurrir "si se entroniza la anarquía”. ${ }^{76}$

Esa era la complicada situación cuando Alvear se hizo cargo del ejército. El nuevo general en jefe se movilizó sobre los rebeldes, consiguió apresar a Bernabé Rivera y a los cuatro sargentos que habían dirigido el motín de julio. En septiembre

\footnotetext{
73 Carta escrita en Durazno el 22 de julio de 1826, AGN/A, X, 7-10-4.

74 PAZ, ob. cit., p. 428. Lo anotó el 16 de julio de 1826.

75 La cita de Rivera en el escrito que envió a Joaquín Suárez desde el Río Negro el 9 de agosto de 1826; la información de Lavalleja en nota de Rodríguez a Núñez del 8 de agosto. Ambas en AGN/A, X, 7$10-4$.

${ }^{76}$ Respectivamente: nota de Raña, el 7 de septiembre de 1826, en el apéndice de BALDRICH, ob. cit., p. 415; PAZ, ob. cit., p. 427.
} 
también Raña depuso su actitud, se disculpó, y las tropas fueron reincorporadas al ejército sin castigos. 77

Ahora sí, todo parecía listo, aunque se dio una paradoja: mientras el ejército finalmente consolidaba su existencia, todo lo demás empezaba a derrumbarse. La inflación y la crisis económica se incrementaron. El papel moneda emitido en Buenos Aires era rechazado en otras provincias y los pagos se complicaban. ${ }^{78}$ Políticamente, las acciones del Congreso trastocaron el equilibrio de las Provincias Unidas. Ya en 1825 algunos diputados de Córdoba buscaron y obtuvieron el apoyo de otros representantes para intentar desplazar a su gobernador Juan Bautista Bustos, quien resistió y desde entonces casi rompió relaciones con el gobierno central. En Catamarca hubo una revolución que alineó a la provincia con los unitarios y en Tucumán sucedió lo mismo cuando Gregorio Aráoz Lamadrid, quien había sido enviado a reclutar el contingente de esa provincia para el ejército de operaciones, se apoderó del poder provincial en noviembre de 1825. Estos cambios en consonancia con el Congreso llevaron a Facundo Quiroga, líder de La Rioja, a dejar de apoyar la opción unitaria para convertirse en un referente federal. En agosto de 1826 empezó a haber enfrentamientos militares en varias provincias andinas, en los que el riojano fue protagonista. La ofensiva política unitaria de ese año llevó también a Santiago del Estero y a Santa Fe a la oposición abierta, en nombre del federalismo. Esta última dio asilo a Fructuoso Rivera, quien había caído en desgracia; acusado de connivencia con los brasileños fue encarcelado en Buenos Aires, aunque huyó y se refugió en aquella provincia.79

La Junta de Representantes oriental se plegó a las directivas del gobierno nacional, pero el cónsul británico en Montevideo observó en octubre de 1826 que las intromisiones de aquel habían hecho nacer un partido independentista oriental, que

\footnotetext{
77 Alvear narró con detalle la operación en Exposición que hace el general Alvear para contestar al mensaje del gobierno del 14 de septiembre de 1827, Edición de la "Biblioteca del oficial”, Buenos Aires, Taller Gráfico de Luis Bernard, 1925, pp. 41-44.

${ }^{78}$ Un ejemplo es el aviso al respecto que hizo Juan Garrigó en Paraná (9 de mayo de 1826, AGN/A, X, 4-4-5).

79 Puede verse una muy buena síntesis de todo esto en HALPERIN DONGHI, Tulio, De la revolución de independencia a la confederación rosista, Buenos Aires, Paidós, 1972.
} 
quería separarse tanto de los brasileños como de los porteños. ${ }^{80} \mathrm{Y}$ en la misma Buenos Aires el proyecto unitario entró en crisis: la agitación en la campaña era grande tanto por la gran leva como por los ataques indígenas, que recrudecieron ese año, y por el malestar con la división de la provincia en dos decidida por el Congreso, una medida que llevó a un sector de la elite conducido por Juan Manuel de Rosas a cambiar de fidelidad política y virar hacia el partido federal. En medio de la agitación, circuló hacia fin de año en la campaña el rumor de que desde Santa Fe y Entre Ríos se atacaría la provincia, y que participaría Rivera al frente de muchos desertores. ${ }^{81}$

Obviamente los conflictos afectaron al envío de tropas para luchar contra el Brasil. Bustos le escribió a Lavalleja afirmando su apoyo a la recuperación de la libertad oriental, pero lamentando "que los tiranos de Buenos Aires no hubiesen adoptado la inicua marcha que han puesto en planta, porque esta Provincia cumpliendo con sus votos le hubiese remitido más brazos; pero ahora estamos desengañados que quieren brazos de los Pueblos para subyugarlos." ${ }^{2}$ Los miedos del gobernador cordobés parecían justificados: un sector unitario encabezado por Agüero empezó a imaginar que poner fin a la guerra con el Imperio le permitiría al gobierno imponer su autoridad sobre las provincias. El ministro estaba convencido de que era "necesario nacionalizar y organizar al país, y esto no se puede hacer sino de dos modos: o ha de ser por la fuerza de los principios, o por el poder de la fuerza", es decir, "con una expresión vulgar, a palos". ${ }^{3}$ Sin embargo, el presidente Rivadavia se mostraba comprometido con la guerra y volcó los recursos porteños a financiar al ejército nacional, para que pudiese finalmente abrir la campaña. ${ }^{84}$

\footnotetext{
80 FREGA, Ana, "La mediación británica en la guerra entre las Provincias Unidas y el imperio del Brasil (1826-1828), Una mirada desde Montevideo", en FREGA, Historia regional e independencia..., ob. cit., p. 119.

${ }^{81}$ FRADKIN, ob. cit., p. 179.

82 Archivo del General Juan A. Lavalleja, T. I, ob. cit., p. 184, carta del $1^{\circ}$ de septiembre de 1826.

83 Cit. en GOLDMAN, Noemí, "Constitución y representación: el enigma del poder constituyente en el Río de la Plata, 1808-1830”, Antonio ANNINO; Marcela TERNAVASIO (coords.), El laboratorio constitucional iberoamericano: 1807/1808-1830, Madrid, AHILA-Iberoamericana-Vervuert, 2012, p. 211 y ss.

${ }^{84}$ Sobre Rivadavia durante la guerra ver GALLO, Klaus, Bernardino Rivadavia. El primer presidente argentino, Buenos Aires, Edhasa, 2012, p. 154 y ss. También REAL DE AZÚA, ob. cit.
} 


\section{"El pabellón republicano será vuestra égida"}

Bajo el mando de Alvear, el ejército se dedicó durante más de tres meses a la instrucción y puesta a punto. Algunos de las cuestiones previas continuaban: "teníamos sin embargo un gran inconveniente", recordó Iriarte, "el considerable número de mujeres (chinas) que acompañaban al ejército". 85 Pero en sus memorias y en todos los escritos de los oficiales del momento consta que la organización avanzaba bien. Llegaban por el Puerto de las Vacas armas, uniformes, caballos, utensilios y dinero fresco (uno de los santos para las tropas, que cambiaba cada día, señalaba su centralidad: "El dinero - Nervio - de la guerra"). ${ }^{86}$

Finalmente, antes de fin de año el ejército estuvo en condiciones de abrir la campaña. Los detalles de su composición en regimientos y su plana de oficiales pueden consultarse en una variada bibliografía. ${ }^{87}$ Se trataba de una fuerza de 6200 hombres (luego se le agregarían refuerzos), en la que primaba la caballería. Todos sabían que el esfuerzo para crearla había sido enorme y que la suerte de la guerra dependía de esa campaña. Alvear proclamó que la Patria estaba pobre y no podía pagar los sueldos, al tiempo que Río Grande estaba atestada de ganados que había sustraído del territorio oriental, y que eso usarían para sustentarse. ${ }^{88}$ El 26 de diciembre los regimientos formaron, aclamaron a su general, y comenzaron la marcha, con "las mujeres a retaguardia de sus respectivas divisiones". ${ }^{89}$

\footnotetext{
85 IRIARTE, ob. cit., p. 377.

86 BRITO DEL PINO, ob. cit., p. 74. Sobre el buen estado del ejército a fines de 1826 véase por ejemplo ARRIETA, Domingo, "Memorias de un soldado", Revista Nacional, Año III, Tomo VII, no 10, Buenos Aires, 1889. El papel pedagógico de esos santos fue señalado por RABINOVICH, "El fenómeno de la deserción...”, ob. cit. Sobre las complejidades organizativas después del período aquí abordado, véase del mismo autor, "La imposibilidad de un ejército profesional: Ramón de Cáceres y el establecimiento de procedimientos burocráticos en las fuerzas del Río de la Plata. 1810-1830”, Quinto Sol, Vol. 17, No 1, 2013, pp. 1-24.

87 BALDRICH, ob. cit., pp. 140-147; COMANDO EN JEFE DEL EJÉRCITO, Reseña histórica y orgánica del ejército argentino, Buenos Aires, Círculo Militar, 1971, p. 352. También BEVERINA, ob. cit.

88 TODD, ob. cit., p. 20.

89 Escritos del coronel D. Federico de Brandsen, Buenos Aires, Comisión Nacional del Centenario de la Independencia Argentina, 1910, p. 250.
} 
En la intensa instrucción final, los oficiales pusieron el énfasis en la disciplina de las tropas para que funcionaran con eficacia. Sabían que en el combate también apelarían a la masculinidad: aludir al honor y la hombría era una manera de motivar la acción en el campo de batalla, más eficaz que otras. Los orientales querían la libertad de su tierra, al tiempo que en ellos y otros estaba presente la vieja enemistad con los portugueses, y en muchos soldados podía jugar también el ansia de tomar algún botín. La oficialidad procuró atenuar las diputas provinciales y fortalecer un espíritu nacional. Pero con la llegada de Alvear hubo un cambio en la concepción del ejército, en cómo se presentaría ante el enemigo.

Ya a fines de 1825, Lecor advirtió a la Corte en Rio de Janeiro que en impresos de Buenos Aires había "doctrinas muy peligrosas", que buscaban "separar de sus deberes a los honrados brasileños" difundiendo en el Imperio "papeles incendiarios". Era "la provincia de São Pedro", es decir Rio Grande do Sul, "la que está más expuesta al contagio por la proximidad de los rebeldes". ${ }^{\circ 0}$ Por cierto, desde que empezó el conflicto, Rivera, Lavalleja y Rodríguez entablaron en distintos momentos contactos con jefes imperiales riograndenses, como Bento Manuel y Bento Gonçalves. El temor de Lecor era a la propagación de ideas republicanas. Y no estaba errado, ya que la idea de exportar el sistema republicano al Brasil estuvo presente desde el principio entre los rioplatenses. El impreso que anunció en Buenos Aires la declaración de guerra proclamaba "que los pueblos brasileros tengan en nosotros un ejemplo que reanime su coraje para arrojar el azote que los degrada y los consume; y que las Repúblicas aliadas vean siempre las banderas de las Provincias-Unidas del Rio de la Plata flamear a la vanguardia en la guerra de la libertad”, para terminar arengando: "iBravos, que habéis dado la independencia a nuestra Patria! Descolgad vuestras espadas. Un Rey, nacido del otro lado de los mares insulta nuestro reposo y amenaza la gloria y el honor de nuestros hijos. iA las armas, compatriotas! ia las armas!" 91

90 Carta al Barão de Valença desde la sitiada Montevideo, 12 de noviembre de 1825, Arquivo Nacional (Rio de Janeiro), fondo Cisplatina, Officios do Barão da Laguna, $2^{\mathrm{a}}$ parte, 162. Traducción mía del portugués.

${ }_{91}$ Impreso de 1825, en AGN, VII, 2669 (archivo Andrés Lamas). 
En la década de 1820 la república era un principio muy poderoso en los nuevos países independientes de Hispanoamérica. Muchos veían a América como tierra de libertad contra una Europa monárquica y por lo tanto atrasada. Según un periódico porteño que en 1825 exigía apoyar a los orientales: "esta es una guerra popular; de la república contra el imperio que la amenaza; de la civilización contra la barbarie, y de las virtudes contra el despotismo más insultante”, para agregar que si "nuestro dictamen pudiera decidir bastaría que se viera un trono en el Brasil, para que se hiciera la guerra, porque su existencia es tan incompatible con nuestros principios, como el agua para sostener el fuego" (es interesante que lo bárbaro era la monarquía y lo civilizado la república, acepción distinta a la que se usaría más tarde). ${ }^{92}$ Era una concepción extendida: un periódico chileno sostuvo sobre el conflicto que "ha comenzado en 826 la guerra de principios, la guerra exclusivamente americana", debido a que "el sistema puramente europeo se ha trasplantado al Brasil (...) Pedro $1^{\circ}$ es el hijo predilecto de la santa alianza, y sus legiones forman la vanguardia de ese torrente inundador que nos amenaza”. $93 \mathrm{El}$ Congreso rioplatense envió una misión ante Simón Bolívar y Antonio José de Sucre, en la flamante Bolivia, para concretar una alianza republicana contra los imperiales. Y uno de los santos del ejército mientras se preparaba en la Provincia Oriental fue: "República - en América - nomás”. 94

El Congreso reemplazó el nombre Provincias Unidas por República Argentina, denominación singular que armonizaba mejor con el proyecto unitario. Mientras Rodríguez firmaba como general del "ejército nacional”, Alvear lo haría como jefe del "ejército de la república". Varios oficiales llamaban al conflicto "guerra contra el emperador del Brasil” y no solo ocurría entre los jefes; un marinero voluntario llamado Gregorio Cardoso sostuvo "que cuando se enganchó fue bajo convencimiento de ir a hostilizar al Imperio del Brasil con quien la República se

\footnotetext{
92 El Argentino, Buenos Aires, 14 de mayo y 2 de junio de 1825. Sobre la prensa republicana en el Río de la Plata y la defensa de la monarquía de la prensa brasileña véase PIMENTA, ob. cit., p. 273.

${ }_{93}$ El Patriota Chileno, tomo 1, $\mathrm{n}^{\circ}$ 14, Santiago, 18 de marzo de 1826.

94 BRITO DEL PINO, ob. cit., p. 74. Sobre la misión véase MILLINGTON, Thomas, Colombia's military and Brazil's monarchy: undermining the republican foundations of South American independence, Westport, Greenwood Press, 1996.
} 
hallaba en guerra." $95 \mathrm{El}$ republicanismo era un principio que se había vuelto exitoso en toda la sociedad y no generaba divisiones internas. La voluntad de "nacionalizar", en cambio, despertaba resistencias locales.

La proclama de Alvear al iniciar la campaña, dirigida a los brasileños, afirmaba que llevaban la "igualdad, don de los cielos, patrimonio de la América, de la cual solo vosotros estáis excluidos aún" y les aseguraba que "el pabellón republicano será vuestra égida". Finalmente, cuando la fuerza inició su marcha había adoptado un nombre nuevo: "ejército republicano". ${ }^{96}$

En la práctica no impulsó un cambio republicano y se comportó en Rio Grande como una fuerza invasora, al estilo de todos los ejércitos de la época, saqueando algunas poblaciones y arreando ganado. Militarmente fue eficaz: obtuvo algunos éxitos en combates menores mientras buscaba una batalla campal decisiva, la consiguió en Ituzaingó en febrero de 1827 y salió victorioso. Pero no pudo aprovechar el triunfo al no perseguir a los imperiales, y luego quedó paralizado por las deserciones y la falta de infantería y de recursos. Poco después, tras una fallida gestión de paz, el gobierno unitario de desmoronó y el Congreso fue disuelto. Buenos Aires, ahora federal, siguió al frente de la guerra, pero exhausta económicamente ya no pudo remontar el ejército. El resultado fue la paz, por la cual los brasileños abandonaban la Banda Oriental, pero esta se convertía en una república independiente. 97

\section{Conclusiones}

El ensayo de Estado "nacional" de 1825-1827 no estaba en condiciones de sostener una guerra de envergadura. Su antagonista, que parecía más sólido, tampoco lo estaba en realidad. Tanto a las fuerzas republicanas como a las imperiales

95 AGN, X, 29-10-5, Sumarios Militares, 246 (1828).

${ }^{96}$ La proclama en el apéndice de Exposición que hace el general Alvear..., ob. cit., p. 109.

${ }_{97}$ Sí se creó en otro ejército, "del Norte”, que al mando de Fructuoso Rivera atacó al imperio en la región misionera en 1828; véase FREGA, Ana, "La 'campaña militar' de las Misiones en una perspectiva regional: lucha política, disputas territoriales, y conflictos étnico-sociales”, en FREGA, Historia regional e independencia..., cit., p. 147 y ss. Los intentos desde Buenos Aires para relanzar la guerra, y la llegada a la paz, pueden verse en DI MEGLIO, Manuel Dorrego, ob. cit., pp. 311-324. 
les costó muchísimo llevar adelante el conflicto, movilizarse y llegar al combate. Puede decirse que la guerra terminó porque ninguno estaba en condiciones de seguir luchando.

La formación del ejército, apuesta clave de los unitarios en su proyecto “nacionalizador", desencadenó una serie de fenómenos que volvieron a este inviable. El esfuerzo económico en pleno bloqueo brasileño dio lugar a una crisis inflacionaria. La magnitud y los abusos del reclutamiento forzoso provocaron reacciones en poblaciones acostumbradas desde la Revolución a movilizarse por sus derechos, ayudando a que en los años venideros la movilización popular se perpetuara en distintos espacios. Las intervenciones en algunas provincias en nombre del gobierno nacional y con excusa de la guerra, como la llevada adelante por Lamadrid en Tucumán o la prepotencia de Rodríguez para subordinar a entrerrianos, correntinos y orientales, incrementaron las resistencias contra el plan de establecer un Estado centralista. Y también favorecieron la aceptación de una solución independentista en la Provincia Oriental.

Aun así, hasta cierto punto el ejército republicano fue el único ámbito en el que cual el plan "nacionalizador" de los unitarios tuvo éxito, en particular entre los oficiales. Buena parte de ellos culpó a los "anarquistas" y "caudillos" por la imposibilidad de continuar la guerra. Al retornar del frente esos oficiales relanzaron a su modo el proyecto unitario y provocaron una guerra civil en la que terminaron vencidos. Varias veces se ha señalado que muchas décadas más tarde, después de la guerra de la Triple Alianza, la oficialidad del ejército nacional sería decisiva, a través de su acción represiva, para consolidar el Estado argentino frente a cualquier desafío a su autoridad. ${ }^{8}$ En cambio, sus "antecesores" que lucharon la guerra con el Brasil tuvieron mucha menos suerte: representantes de un ejército detrás del cual ya no existía el Estado que lo había formado, les fue imposible imponer una solución propia, someter "a palos" a las provincias para revivir a ese poder central. Las

98 Sobre todo OSZLAK, Oscar, La formación del Estado argentino, Buenos Aires, Editorial de Belgrano, 1981. 
provincias continuaron siendo las unidades políticas fundamentales.99 $\mathrm{Y}$ el federalismo fue el resultado de su victoria.

$\mathrm{oOo}$

\section{Fuentes citadas}

Archivo del General Juan A. Lavalleja, T. I, Montevideo, Archivo General de la Nación de la República Oriental del Uruguay, 1935.

ARCHIVO GENERAL DE LA NACIÓN (Buenos Aires), sala X: legajos 4-4-4, 4-4-5, 4-4-6, 4-4-7, 4-5-1, 7-10-4, 14-2-1, 22-5-8, 22-7-2, 29-9-9, 29-10-5, 29-11-5.

ARCHIVO GENERAL DE LA NACIÓN (Montevideo) Archivo del ejército, caja 352.

ARQUIVO NACIONAL (Rio de Janeiro), fondo Cisplatina, Officios do Barão da Laguna.

ARRIETA, Domingo, "Memorias de un soldado", Revista Nacional, Año III, Tomo VII, $\mathrm{n}^{0}$ 10, Buenos Aires, 1889.

BERUTI, Juan Manuel, "Memorias curiosas", Biblioteca de Mayo. Colección de obras y documentos para la historia argentina, Buenos Aires, Senado de la Nación, T. IV, 1960.

Boletín Histórico, Estado Mayor del Ejército, Montevideo, nº 27-28 (1947), 34, 35 (1948), 37, 39 (1949).

BRITO DEL PINO, José, Diario de la guerra del Brasil, Montevideo, 1956.

Diario de sesiones de la Honorable Junta de Representantes de la Provincia de Buenos Aires, 1823.

Escritos del coronel D. Federico de Brandsen, Buenos Aires, Comisión Nacional del Centenario de la Independencia Argentina, 1910.

Exposición que hace el general Alvear para contestar al mensaje del gobierno del 14 de septiembre de 1827, Edición de la "Biblioteca del oficial" anotada por el Teniente Coronel Juan BEVERINA, Buenos Aires, Taller Gráfico de Luis Bernard, 1925.

El Argentino, Buenos Aires.

El Patriota Chileno, tomo 1, Santiago de Chile.

El Tribuno, Buenos Aires.

IRIARTE, Tomás de, Memorias, vol. 3 ("Rivadavia, Monroe y la guerra argentinobrasileña”), Buenos Aires, Sociedad Impresora Americana, 1945.

99 Véase CHIARAMONTE, José Carlos, "La cuestión regional en el proceso de gestación del estado nacional argentino. Algunos problemas de interpretación", en Marcos PALACIO (comp.), La unidad nacional en América Latina: del regionalismo a la nacionalidad, México, El Colegio de México, 1983, pp. 51-85. 
PAZ, José María, Memorias póstumas, T. II, Buenos Aires, Ediciones Estrada, 1957.

RAVIGNANI, Emilio (comp.), Asambleas Constituyentes Argentinas, Instituto de Investigaciones Históricas de la Facultad de Filosofía y Letras, Tomo I, Buenos Aires, 1937.

ROJAS, Manuel, "Memoria”, Revista Nacional, Año III, Tomo VII, nº 34, Buenos Aires, 1889.

TODD, José María Recuerdos del ejército de operaciones contra el emperador del Brasil, Buenos Aires, Betograf, 1959.

\section{Bibliografía citada}

BALDRICH, Juan Amadeo, Historia de la guerra del Brasil, Buenos Aires, Eudeba, 1974 .

BARRÁN, José Pedro, “La independencia y el miedo a la revolución social en 1825”, Revista de la Biblioteca Nacional. nº 24, Montevideo, 1986.

BEVERINA, Juan, La guerra contra el imperio del Brasil, Biblioteca del Oficial, Buenos Aires, 1927.

CHIARAMONTE, José Carlos, "La cuestión regional en el proceso de gestación del estado nacional argentino. Algunos problemas de interpretación”, en Marcos PALACIO (comp.), La unidad nacional en América Latina: del regionalismo a la nacionalidad, México, El Colegio de México, 1983.

COMANDO EN JEFE DEL EJÉRCITO, Reseña histórica y orgánica del ejército argentino, Buenos Aires, Círculo Militar, 1971.

DI MEGLIO, Gabriel, iViva el bajo pueblo! La plebe urbana de Buenos Aires y la política entre la Revolución de Mayo y el rosismo, Buenos Aires, Prometeo Libros, 2006.

DI MEGLIO, Gabriel, Manuel Dorrego. Vida y muerte de un líder popular, Buenos Aires, Edhasa, 2014.

FRADKIN, Raúl, La Historia de una montonera. Bandolerismo y caudillismo en Buenos Aires, 1826, Siglo XXI, Buenos Aires, 2006.

FRADKIN, Raúl; GELMAN, Jorge, Juan Manuel de Rosas. La construcción de un liderazgo político, Buenos aires, Edhasa, 2015.

FREGA, Ana: “Uruguayos y orientales: itinerario de una síntesis compleja”, José Carlos CHIARAMONTE, Carlos MARICHAL y Aimer GRANADOS (comps.), Crear la nación. Los nombres de los países de América Latina, Buenos Aires, Sudamericana, 2008.

FREGA, Ana, "La mediación británica en la guerra entre las Provincias Unidas y el imperio del Brasil (1826-1828), Una mirada desde Montevideo”, en Ana FREGA (coord.), Historia regional e independencia del Uruguay. Proceso histórico y revisión crítica de sus relatos, Montevideo, Ediciones de la Banda Oriental, 2009. 
FREGA, Ana, “La 'campaña militar' de las Misiones en una perspectiva regional: lucha política, disputas territoriales, y conflictos étnico-sociales", en Ana FREGA (coord.), Historia regional e independencia del Uruguay. Proceso histórico y revisión crítica de sus relatos, Montevideo, Ediciones de la Banda Oriental, 2009.

FREGA, Ana (coord.) Los orientales en armas: estudios sobre la experiencia militar en la revolución artiguista, Montevideo, CSIC, 2015.

GALLO, Klaus, Bernardino Rivadavia. El primer presidente argentino, Buenos Aires, Edhasa, 2012.

GOLDMAN, Noemí, "Constitución y representación: el enigma del poder constituyente en el Río de la Plata, 1808-1830", Antonio ANNINO; Marcela TERNAVASIO (coords.), El laboratorio constitucional iberoamericano: 1807/1808-1830, Madrid, AHILA-Iberoamericana-Vervuert, 2012.

HALPERIN DONGHI, Tulio, De la revolución de independencia a la confederación rosista, Buenos Aires, Paidós, 1972.

HALPERIN DONGHI, Tulio, Guerra y finanzas en los orígenes del estado argentino (1791-1850), Buenos Aires, Editorial de Belgrano, 1982.

ISLAS, Ariadna: "Límites para un Estado. Notas controversiales sobre las lecturas nacionalistas de la Convención Preliminar de Paz de 1828", en Ana FREGA (coord.), Historia regional e independencia del Uruguay. Proceso histórico y revisión crítica de sus relatos, Montevideo, Ediciones de la Banda Oriental, 2009.

LUFT, Marcos Vinícios, "Essa guerra desgraçada": recrutamento militar para a Guerra da Cisplatina (1825-1828), tesis de maestría, Universidade Federal do Rio Grande do Sul, Porto Alegre, 2013.

MEISEL, Seth, "The Politics of Seduction: Mutiny and Desertion in Early Nineteenth-Century Cordoba”, Jane HATHAWAY, Rebellion, Repression, Reinvention: Mutiny in Comparative Perspective, Westport, Praeger, 2001.

MILLINGTON, Thomas, Colombia's military and Brazil's monarchy: undermining the republican foundations of South American independence, Westport, Greenwood Press, 1996.

OSZLAK, Oscar, La formación del Estado argentino, Buenos Aires, Editorial de Belgrano, 1981.

PIMENTA, João Paulo, Estado y nación hacia el final de los Imperios ibéricos. Río de la Plata y Brasil, 1808-1828, Buenos Aires, Sudamericana, 2011.

RABINOVICH, Alejandro, "El fenómeno de la deserción en las guerras de la revolución e independencia del Río de la Plata: 1810-1829" E.I.A.L., vol. 2, n ${ }^{\circ}$ $1,2011$.

RABINOVICH, Alejandro, "La imposibilidad de un ejército profesional: Ramón de Cáceres y el establecimiento de procedimientos burocráticos en las fuerzas del Río de la Plata. 1810-1830", Quinto Sol, Vol. 17, Nº 1, 2013. 
REAL DE AZÚA, Carlos, Los orígenes de la nacionalidad uruguaya, Montevideo, Arca, 1990.

SALTERAIN Y HERRERA, Eduardo, Lavalleja. La redención patria, tomo II, Montevideo, Publicaciones de la Comisión Nacional de Homenaje del Sesquicentenario de los Hechos Históricos de 1825, 1975.

SCHMIT, Roberto, Ruina y resurrección en tiempos de guerra: sociedad, economía $y$ poder en el oriente entrerriano posrevolucionario, 1810-1852, Buenos Aires, Prometeo Libros, 2004.

TERNAVASIO, Marcela: "Las reformas rivadavianas en Buenos Aires y el Congreso General Constituyente (1820-1827)", en Noemí GOLDMAN (dir.) Nueva Historia Argentina, vol 3, Buenos Aires, Sudamericana, 1998.

WASSERMAN, Fabio, "Revolución y nación en el Río de la Plata (1810-1860)", AAVV, La construcción de la nación argentina. El rol de las fuerzas armadas, Buenos Aires, Ministerio de Defensa, 2010. 